\title{
Hubungan Antara Peran Pengawas Menelan Obat (PMO) dengan Keberhasilan Pengobatan Tuberkulosis Paru Kategori I

\author{
Selly Septi Fandinata ${ }^{*}$, Rizky Darmawan ${ }^{2}$ \\ 1,2 Farmasi, Akademi Farmasi Surabaya, \\ Jl. Ketintang Madya No. 81 Kota Surabaya 60231, Indonesia
} \\ *Penulis Korespondensi.Email: sellyfandinata@akfarsurabaya.ac.id
}

\section{ABSTRAK}

TB adalah suatu penyakit menular yang disebabkan oleh kuman mycobacterium tuberculosis yang menyerang paru-paru dan dapat menimbulkan gangguan pada saluran nafas. Program DOTS dapat membantu tercapainya target keberhasilan pengobatan. Peran dan motivasi PMO dan keluarga sangat penting untuk keberhasilan pengobatan penderita TB paru. Jenis penelitian ini adalah penelitian observasional analitik dengan pengumpulan data secara prospektif pada bulan Maret - Mei 2019 yang berupa data rekam medik pasien yang terdiagnosa TB paru kategori I pada bulan September - November 2018 di Puskesmas Rubaru Kabupaten Sumenep. Tujuan dari penelitian ini untuk mengetahui hubungan peran PMO dengan keberhasilan pengobatan TB Paru Kategori I.dengan jumlah sampel pd penelitian ini sebanyak 40 pasien.Hasil penelitian ini menggunakan statistik korelasi pearson menunjukkan bahwa nilai signifikansi $0.013<0.05$, ini berarti hubungan signifikan antara peran PMO dengan keberhasilan pengobatan pasien. Nilai koefisien korelasi $\mathrm{R}$ diperoleh 0.388 , maka hubungan antara peran PMO dan keberhasilan pengobatan pasien searah, ini artinya semakin besar peran PMO maka semakin tinggi keberhasilan pengobatan, sebaliknya semakin kecil peran PMO maka semakin rendah keberhasilan pengobatan. Selain itu dari tabel tersebut juga diperoleh bahwa hubungan antara peran PMO dengan keberhasilan pengobatan pasien tergolong lemah karena koefisien korelasi $\mathrm{R}<0.4$.

Kata Kunci:

TB Kategori I, PMO, Keberhasilan Pengobatan

$\begin{array}{ccc}\text { Diterima: } & \text { Disetujui: } & \text { Online: } \\ \text { 22-07-2019 } & 28-08-2019 & 12-09-2019\end{array}$




\section{ABSTRACT}

$T B$ is an infectious disease caused by Gercobacterium tuberculosis that attacks the lungs and can cause disturbances in the respiratory tract. The DOTS Program can help the achievement of successful treatment targets. The role and motivation of PMO and family are essential for the successful treatment of lung TB patients. This type of study is an analytical observational research with prospective data collection in March - May 2019, which is recorded as medical data of patients diagnosed with lung TB category I in September - November 2018 at Rubaru Puskesmas Sumenep Regency. The purpose of this research is to know the role of PMO relationship with the successful treatment of lung TB category I. With the number of samples of this research 40 patients. The results of this study using Pearson correlation statistics indicate that the value significance $0.013<0.05$, this means a significant link between the PMO role with the success of patient treatment. The value of the correlation coefficient $R$ obtained from 0388, the relationship between PMO role and the success of patient treatment in direct, this means that the greater the role of PMO then the higher the success of treatment, the smaller the PMO role then the lower the Successful treatment. In addition, the table also gained that the relationship between the PMO role and the successful treatment of the patient is weak due to the correlation coefficient of $R<0.4$.Copyright $(0) 2019$ Jsscr. All rights reserved.

Keywords:

TB category I, PMO, Success treatment

$\begin{array}{ccc}\text { Received: } & \text { Accepted: } & \text { Online: } \\ \text { 2019-07-22 } & \text { 2019-08-28 } & 2019-09-12\end{array}$

1. Pendahuluan

Penyakit tuberkulosis (TBC) adalah penyakit kronis menular yang masih tetap merupakan masalah kesehatan masyarakat di dunia termasuk Indonesia. Penyakit Tuberkulosis penyakit lama yang masih menjadi pembunuh terbanyak diantara penyakit menular. Dunia pun masih belum bebas dari TBC. Berdasarkan laporan WHO 2017 diperkirakan ada 1.020.000 kasus di Indonesia. Indonesia menduduki peringkat ke2 di dunia dalam jumlah kasus TB, baik dalam jumlah keseluruhan kasus maupun kasus baru. TBC telah membunuh tiga juta orang pertahun. Diperkirakan, kasus TBC meningkat 5-6 persen dari total kasus [1]. Berdasarkan data pravelensi TB dari Dinkes pada tahun 2015, Jawa Timur menempati urutan ke dua di Indonesia dalam jumlah penemuan TB BTA Positif kasus baru dan menempati urutan ke delapan dari 33 provinsi di Indonesia. Pada tahun 2016 kota Sumenep mengobati penderita TB paru sebanyak 944 penderita dengan 790 sembuh $(92,27 \%)$. Tahun 2016 penderita TB paru BTA positif di Puskesmas Rubaru Sumenep sebanyak 51 orang dan presentase keberhasilan pengobatan mencapai $100 \%$. Presentase keberhasilan pengobatan ini lebih tinggi dari Puskesmas Pragaan yang hanya mencapai $88 \%$ dari 72 penderita karena masih ada 8 penderita masih dalam pengobatan [2].

Tuberkulosis (TB) adalah suatu penyakit menular yang disebabkan oleh kuman mycobacterium tuberculosis yang menyerang paru-paru dan dapat menimbulkan gangguan pada saluran nafas dikenal sebagai Mycobacterium Other Than Tuberculosis (MOTT), dan juga dikenal sebagai Bakteri Tahan Asam (BTA), kuman ini berbentuk batang dengan panjang 1-10 mikron, lebar 0,2-0,6 mikron dan sangat peka terhadap panas,sinar matahari dan sinar ultra violet, dan bersifat dorman. [2]. Orang yang terdiagnosis TB BTA positif merupakan penularan yang mengandung kuman TB dalam dahaknya. Penularan dapat melalui batuk atau bersin, pasien menyebarkan kuman ke udara dalam bentuk percikan dahak (droplet nuclei / percik renik). Infeksi akan terjadi apabila seseorang menghirup udara yang mengandung percikan dahak infeksius. Sekali batuk dapat menghasilkan sekitar 3000 percikan dahak, penularan terjadi dalam ruagan dimana percikan dahak berada dalam waktu yang lama sementara sinar matahari 
langsung dapat membunuh kuman,percikan dapat bertahan selama beberapa jam dalam keadaan yang gelap dan lembab. [3].

Target program penanggulangan TB adalah tercapainya penemuan penderita baru TB dengan BTA positif paling sedikit 70\% dari perkiraan dan menyembuhkan 85\% dari semua penderita tersebut serta mempertahankannya. Target ini diharapkan dapat menurunkan tingkat prevalensi dan kematian akibat TB hingga separuhnya pada tahun 2010 dibanding tahun 1990 dan mencapai tujuan millenium development goals (MDGs) pada tahun 2015. Indonesia memang telah banyak mencapai kemajuan, yakni penemuan kasus baru 51,6\% dari target global 70\% dan penyediaan obat anti TB yang mencukupi kebutuhan perkiraan kasus di seluruh Indonesia, namun TB belum dapat diberantas, bahkan diperkirakan jumlah penderita TB terus meningkat [3]. Kenyataan mengenai penyakit TB diIndonesia begitu mengkhawatirkan, sehingga kita harus waspada sejak dini dan mendapatkan informasi lengkap tentang penyakit TB. Apabila hal ini tidak mendapat perhatian dan penanganan yang tepat, cepat, segera dan intensif, maka prevalensi penyakit ini akan terus meningkat serta risiko penularan pun semakin tinggi. Berbagai upaya telah dilakukan oleh pemerintah untuk mengurangi virulensi dan menekan jumlah penderita tuberkulosis, diantaranya dengan dicanangkannya Gerakan Terpadu Nasional (Gardunas TB) oleh Menkes RI pada tanggal 24 Maret 1999. Pemerintah melalui Program Nasional Pengendalian TB telah melakukan berbagai upaya untuk menanggulangi TB, yakni dengan strategi DOTS. World Health Organization (WHO) merekomendasikan 5 komponen strategi DOTS, antara lain dengan pengawasan langsung Pengawas Minum Obat (PMO).

Pelaksanaan strategi DOTS sudah dilaksanakan tetapi sampai saat ini penderita tuberkulosis di Indonesia masih tinggi. Perlu dilakukan suatu modifikasi strategi untuk meningkatkan keteraturan minum OAT bagi penderita TB [4]. Penderita TB perlu pengawasan langsung agar meminum obat secara teratur sampai sembuh [3]. Orang yang mengawasi dikenal dengan istilah PMO (Pengawas Minum Obat). PMO sebaiknya orang yang dekat dan disegani oleh penderita TBC, misalnya keluarga, tetangga, atau kader kesehatan. PMO bertanggung jawab untuk memastikan penderita TB meminum obat sesuai anjuran petugas Puskesmas/UPK (Unit Pelayanan Kesehatan). Penderita TB mungkin saja merasa malu atau kesakitan karena mengidap TB, maka PMO harus bisa menjadi sahabat yang siap mendengarkan keluhan penderita dan bisa membuat penderita merasa nyaman [5].

Penyakit Tuberkulosis dapat disembuhkan dengan pengobatan secara teratur. Keberhasilan pengobatan dipengaruhi beberapa factor mulai dari karakteristik penderita termasuk status gizi dan imunitas, factor lingkungan, factor sarana dan prasarana yang mendukung keteraturan pengobatan. Karena pengobatan TB memerlukan waktu yang sangat panjang dan mungkin menyababkan kebosanan dan kejenuhan pada penderita. Untuk menjamin keteraturan pengobatan tersebut diperlukan seorang Pengawas Menelan Obat (PMO yang akan membantu penderita selama dalam program pengobatan ТВ [6]. Kesembuhan pasien dapat dicapai hanya bila pasien dan petugas pelayanan kesehatan bekerjasama dengan baik dan Pengawas Menelan Obat (PMO) harus mengamati setiap asupan obat bahawa OAT yang ditelan oleh pasien adalah tepat obat, tepat dosis dan interval [7]. Umumnya penderita minum obat selama 6 bulan untuk memastikan kesembuhannya, namun pada beberapa keadaan dapat berbeda dapat lebih lama. Sehingga Peran pengawas menelan obat 
sangat penting dalam rangka penyembuhan penderita tuberkulosis paru, sehingga pelaksanaan Program Pemberantasan Penyakit TB (P2TB) sangat diperlukan evaluasi untuk mengetahui tingkat keberhasilannya [4].

Berdasarkan jurnal penelitian yang dilakukan oleh Wahyuni dkk (2016) menunjukkan bahwa dari 45 responden $(80,4 \%)$ berhasil dalam pengobatan TB dan responden dengan PMO kategori berperan terdapat $40(71,4 \%)$ dengan nilai $\mathrm{P}=1,000(>0,05)$ tidak ada hubungan peran PMO terhadap keberhasilan pengobatan tuberculosis. Penelitian lain yang dilakukan Iceu dkk (2018) dengan judul yang sama menunjukkan bahwa dari 38 responden $(76,0 \%)$ dan hanya 12 responden $(24,0 \%)$ yang tidak berhasil dalam pengobatan $\mathrm{TB}$ dengan nilai $\mathrm{P}=0,008$ ) terdapat hubungan yang signifikan antara peran PMO terhadap keberhasilan pengobatan TB DI Puskesmas Tarogong Garut [8]. Berdasarkan jurnal penelitian yang dilakukan oleh Fatmawati dan Bumbunan Sitorus, (2016) dari Universitas Tanjungpura Pontianak menyatakan bahwa masih kurangnya motivasi keluarga dan PMO dengan latar belakang pendididikan yang kurang, kondisi lingkungan sekitar yang kumuh dan kondisi sosial ekonomi atau pendapatan yang minim akan melemahkan motivasi keluarga dan PMO terhadap kesembuhan dan keberhasilan pengobatan pasien TB paru [9]. Menurut hasil jurnal penelitian lain oleh Latifatul Muna (2014) motivasi dengan kepatuhan berobat dan ada hubungan dukungan sosial keluarga dengan kepatuhan berobat [10]. Penelitian lain yang dilakukan oleh Fitria dkk (2012) menunjukkan terdapat hubungan yang signifikan $(\mathrm{P}=0,000)$ antara pendidikan $\mathrm{PMO}$ dengan keteraturan minum OAT dan terdapat hubungan yang signifikan $(\mathrm{P}=0,000)$ antara pengetahuan $\mathrm{PMO}$ dengan keteraturan minum OAT [11].

Berdasarkan permasalahan di atas dan tingginya angka kejadian TB paru di Indonesia dan data di Puskesmas kabupaten Sumenep walaupun sudah menjalankan strategis DOTS sejak tahun 2010 Ternyata masih ditemukan pasien dengan putus obat. Mengingat bahwa akibat dari pada putus obat dapat berkembang menjadi Multidrugresistant tuberculosis (MDR-TB) dan dapat menularkan kepada orang lain, maka hal tersebut tetap memerlukan perhatian yang serius. Oleh karena itu ingin mengidentifikasi hubungan peran Pengawas Minum Obat (PMO terhadap keberhasilan pengobatan TB kategori I di Puskesmas Wilayah Sumenep.

\section{Metode}

Jenis penelitian ini adalah penelitian observasional korelasional yaitu mengetahui hubungan antara peran pengawas menelan obat (PMO) dengan keberhasilan pengobatan TB Paru kategori I dengan pengumpulan data secara prospektif selama bulan Maret - Mei 2019 yang berupa data rekam medik pasien yang terdiagnosa TB paru kategori I pada bulan September - November 2018 di Puskesmas di wilayah Sumenep. Penelitian dilanjutkan dengan memberikan kuisioner kepada PMO pasien TB Paru kategori I untuk mengukur hubungan peran PMO dengan keberhasilan pengobatan pasien.

Sampel pada penelitian ini adalah Semua PMO pasien TB paru kategori I pada bulan Maret - Mei 2019 di Puskesmas di wilayah Sumenep sesuai kriteria penelitian. Besar sampel adalah total sampling yaitu semua jumlah pasien TB paru kategori 1 pada bulan Maret - Mei 2019 di Puskesmas di wilayah Sumenep.

Cara Pengambilan sampel dalam penelitian ini dilakukan dengan cara purposive sampling, yaitu penentuan sampel yang didasarkan pada suatu pertimbangan tertentu. 
Pada penelitian ini pertimbangan yang ditentukan adalah responden yang menjadi PMO pada pasien yang terdiagnosa TB paru kategori I.

Kriteria Inklusi

1. PMO dan rekam medis Pasien yang terdiagnosa TB paru kategori I pada bulan September - November 2018.

2. PMO dan Pasien yang terdiagnosis TB paru Kategori I yang tinggal menetap di wilayah kerja Puskesmas Sumenep.

3. PMO dan rekam medis pasien yang mendapat terapi obat OAT kategori 1

4. Rekam medis pasien TB Paru kategori I yang disertai hasil konversi BTA pada bulan ke 0 , dan 6

5. PMO pada pasien yang terdiagnosis TB paru kategori I yang mampu berkomunikasi dengan baik dan tidak buta huruf

6. PMO pasien yang bersedia menjadi subjek penelitian.

Kriteria Eksklusi

1. PMO yang tidak mendampingi pasien datang ke Fasyankes pada periode penelitian.

2. PMO yang menjawab kuisioner secara tidak lengkap.

3. Rekam medis pasien dengan hasil konversi BTA tidak lengkap.

4. Rekam medis pasien yang meninggal saat menjalani pengobatan $\mathrm{TB}$ paru kategori 1.

5. Rekam medis pasien pindah ke faskes lain.

Variabel Penelitian

1. Variabel Bebas : Peran PMO yang diukur dari parameter peran mengawasi, motivasi, mengingatkan, serta penyuluhan dalam keberhasilan pengobatan pasien TB paru kategori I.

2. Variabel Terikat : Keberhasilan pengobatan pasien TB paru kategori I yang diukur dari hasil konversi BTA pasien.

\subsection{Bahan / Instrumen}

1. Rekam Medis

2. Inform Consent

3. Kuisioner

\subsection{Analisis data}

Analisa data pada penelitian ini menggunakan korelasi pearson.

\section{Hasil dan Pembahasan}

Berdasarkan hasil penelitian yang dilakukan secara observasional oleh peneliti selama periode penelitian Maret - Mei 2019, diperoleh bahwa besar sampel dari Puskesmas Wilayah Sumenep yang memenuhi kriteria inklusi, didapatkan sebanyak 40 pasien. Kemudian data dikelompokkan secara diskriptif dan dianalisis hubungan antara peran PMO dengan keberhasilan pengobatan pasien TB paru. tersebut menggunakan uji Korelasi Pearson berdasarkan Skor peran PMO diperoleh dari skor total dari masingmaisng skor parameter peran mengawasi, motivasi, mengingatkan, serta penyuluhan. Korelasi Pearson adalah korelasi yang digunakan untuk data kontinu dan data diskrit. Korelasi pearson cocok digunakan untuk statistik parametrik. 


\subsection{Karakteristik Pasien}

Data karakteristik demografi Pasien TB paru kategori 1 meliputi, jenis kelamin, usia, pekerjaan, dan pendidikan, tertuang pada tabel 1. Dari hasil demografi pasien TB kategori 1 di puskesmas wilayah Sumenep pada penelitian ini didapat bahwa jenis kelamin yang paling banyak adalah laki - laki 26 orang (65\%) dan perempuan 14 orang $(35 \%)$. Berdasarkan literature jenis kelamin laki -laki disebabkan karena beban kerja mereka yang berat, istirahat yang kurang serta gaya hidup yang tidak sehat diantaranya adalah merokok dan minum alcohol sehingga dapat dikemukakan bahwa laki - laki lebih rentan terkena penyakit TB paru [12]. Berdasarkan hasil demografi usia pasien pada penelitian ini didapatkan bahwa dari segi usia penderita TB paru kategori 1 terbanyak adalah 26 -35 th (dewasa awal) sebanyak 10 pasien (25\%), dan usia $46-55$ th (lansia awal) sebanyak 10 pasien (25\%).

Tabel .1 Karakteristik Pasien yang terdiagnosa TB paru kategori 1 dan mendapat terapi OAT kategori 1

\begin{tabular}{|c|c|c|c|}
\hline Variabel & Kategori & Jumlah & Presentase $(\%)$ \\
\hline \multirow[t]{2}{*}{ Jenis Kelamin } & Laki-laki & 26 & 65 \\
\hline & Perempuan & 14 & 35 \\
\hline \multirow[t]{6}{*}{ Umur } & 17-25 tahun & 1 & 2,5 \\
\hline & 26-35 tahun & 10 & 25 \\
\hline & 36-45 tahun & 8 & 20 \\
\hline & 46-55 tahun & 10 & 25 \\
\hline & 56-65 tahun & 7 & 17,5 \\
\hline & 65 tahun ke atas & 4 & 10 \\
\hline \multirow[t]{4}{*}{ Pendidikan } & SD & 19 & 47,5 \\
\hline & SMP & 8 & 20 \\
\hline & SMU & 9 & 22,5 \\
\hline & Sarjana & 4 & 10 \\
\hline \multirow[t]{5}{*}{ Pekerjaan } & Petani & 18 & 45 \\
\hline & Pedagang & 4 & 10 \\
\hline & PNS & 3 & 7,5 \\
\hline & Pegawai Swasta & 14 & 35 \\
\hline & Ibu Rumah Tangga & 1 & 2,5 \\
\hline
\end{tabular}

Berdasarkan literature menunjukkan bahwa faktor umur bukan merupakan faktor penentu dalam pengobatan karena yang berusia muda maupun usia lanjut memiliki motivasi untuk hidup sehat dan selalu memperhatikan kesehatannya. Dari segi demografi pekerjaan pasien kebanyakan pada penelitian ini adalah seorang buruh tani sebanyak 18 pasien (45\%), hal ini sejalan dengan penelitian yang dilakukan oleh Arsih (2004) menunjukkan bahwa jenis pekerjaan yang berisiko tinggi terpapar kuman TB 
adalah sopir, buruh/tukang, pensiunan/purnawirawan dan belum bekerja. Pekerjaan merupakan suatu aktifitas yang dilakukan untuk mencari nafkah. Factor lingkungan kerja mempengaruhi seseorang untuk terpapar suatu penyakit. Lingkungan kerja yang buruh mendukung untuk terinfeksi TB Paru antara supir, buruh, tukang becak dibandingkan dengan orang yang bekerja di daerah perkantoran. dan dari segi kategori pendidikan akhir paling banyak SD 19 pasien (47,5\%) [13]. Hal ini dikemukakan pada literature semakin rendah tingkat pendidikan maka semakin mempengaruhi daya serap seseorang dalam menerima informasi sehingga dapat mempengaruhi tingkat pemahaman tentang penyakit TB paru, cara pengobatan, dan bahaya akibat minum obat tidak teratur [12].

\subsection{Karakteristik Demografi PMO}

Data karakteristik demografi PMO Paien TB paru kategori 1 meliputi, jenis kelamin, usia, pekerjaan, dan pendidikan.

Tabel 2 Karakteristik PMO Pasien yang terdiagnosa TB paru kategori 1 dan mendapat terapi OAT kategori 1

\begin{tabular}{llll}
\hline Variabel & Kategori & Jumlah & Presentase (\%) \\
\hline Jenis Kelamin & Laki-laki & 28 & 70 \\
\hline Umur & Perempuan & 12 & 30 \\
\hline & $17-25$ tahun & 3 & 7,5 \\
\hline & $26-35$ tahun & 23 & 57,5 \\
\hline Pendidikan & $36-45$ tahun & 6 & 15 \\
\hline & $46-55$ tahun & 8 & 20 \\
\hline & SD & 0 & 0 \\
\hline & SMP & 3 & 7,5 \\
\hline Pekerjaan & SMU & 14 & 35 \\
\hline & Diploma & 1 & 2,5 \\
\hline & Sarjana & 22 & 55 \\
\hline & Petani & 4 & 10 \\
\hline & Pedagang & 1 & 2,5 \\
\hline & PNS & 17 & 42,5 \\
\hline & Pegawai Swasta & 15 & 37,5 \\
\hline
\end{tabular}

Dari hasil demografi PMO pasien TB kategori 1 di puskesmas wilayah Sumenep pada penelitian ini didapat bahwa jenis kelamin yang paling banyak adalah laki - laki 28 orang $(70 \%)$ dan perempuan 12 orang $(30 \%)$. Hasil ini berbeda dengan penelitian Hapsari (2010), mayoritas penderita TB memiliki PMO berjenis kelamin perempuan disebabkan karena sifat sabar dan telaten yang ada pada perempuan. Berdasarkan hasil demografi usia pasien pada penelitian ini didapatkan bahwa dari segi usia PMO penderita TB paru kategori 1 terbanyak adalah $26-35$ tahun sebanyak 23 pasien $(57,5 \%)$ [14]. Hal ini sesuai dengan gambaran karakteristik PMO yang diharapkan oleh pasien TB Paru. PMO sebaiknya berumur 15 tahun ke atas atau harus disegani oleh pasien TB karena pada usia tersebut emosi seseorang mulai stabil dan mampu menyelesaikan masalah dan menerima tugas dengan tanggung jawab [15]. Dari segi demografi pendidikan PMO pada penelitian ini adalah sarjana sebanyak 22 responden (55\%) dan yang kedua adalah SMU sebanyak 14 responden (35\%). Hal ini didasarkan bahwa PMO yang berpendidikan SMA atau lebih dapat memebrikan penyuluhan, dorongan, memahami gejala, cara penularan, mengerti cara pencegahan komplikasi, dan mengerti 
efek samping dari obat sehingga pengobatan dapat berhasil. Hal ini juga didukung oleh penelitian oleh Hapsari (2010), menyatakan bahwa pendidikan PMO sangat berpengaruh terhadap baik buruknya penyuluhan dan cara memotivasi penderita, makin baik cara memotivasi dan memberikan penyuluhan, akan makin baik pula hasil yang didapat yaitu kepatuhan penderita [14]. Dari segi demografi pekerjaan PMO pada penelitian ini adalah yang paling banyak PNS sebanyak 17 responden $(42,5 \%)$, pegawai swasta sebanyak 15 responden $(37,5 \%)$, petani sebanyak 4 responden $(10 \%)$, ibu rumah tangga sebanyak 3 responden $(7,5 \%)$ dan pedagang sebanyak 1 responden $(2,5 \%)$.

\subsection{Analisa Statistik}

\section{Uji Normalitas}

Sebelum dilakukan uji korelasi, terlebih dahulu dilakukan uji normalitas pada variablevariabel penelitian terakait, yaitu skor peran PMO dan keberhasilan pengobatan. Hal ini dilakukan untuk menentukan jenis uji korelasi apa yang cocok untuk mendapatkan hubungan antara peran PMO dan keberhasilan pengobatan. Uji normalitas yang digunakan dalam penelitian ini adalah uji Kolmogorov Smirnov.

\section{Tabel 3 Uji Normalitas 1}

Tests of Normality

\begin{tabular}{cc|c|c|c|c|c}
\multicolumn{3}{c}{ Kolmogorov-Smirnov $^{\text {a }}$} & \multicolumn{3}{c}{ Shapiro-Wilk } \\
& Statistic & Df & Sig. & Statistic & df & Sig. \\
\hline Xtotal & .398 & 40 & .000 & .660 & 40 & .000 \\
\hline \multicolumn{3}{c}{ a. Lilliefors Significance Correction }
\end{tabular}

Tabel di atas adalah hasil uji normalitas dari variable skor total peran PMO. Nilai dari signifikansi pada bagian Kolmogorov Smirnov didapat $0.00<0.05$, maka data skor peran PMO adalah tidak terdistribusi normal. Selanjutnya di bawah ini adalah hasil uji normalitas dari variable keberhasilan pengobatan.

\section{Tabel 4 Uji Normalitas 2}

Tests of Normality

\begin{tabular}{ccc|c|c|c|c} 
& \multicolumn{4}{c|}{ Kolmogorov-Smirnov $^{\mathrm{a}}$} & \multicolumn{3}{c}{ Shapiro-Wilk } \\
& Statistic & Df & Sig. & Statistic & df & Sig. \\
\hline $\mathrm{Y}$ & .540 & 40 & .000 & .229 & 40 & .000 \\
\hline
\end{tabular}

a. Lilliefors Significance Correction

Pada tabel di atas, di bagian Kolmogorov Smirnov diperoleh signifikansi $0.00<0.05$, maka data keberhasilan pengobatan adalah tidak terdistribusi normal.

\section{Uji Korelasi}

Analisa data yang digunakan dalam penelitian ini menggunakan korelasi Spearman Rank untuk mencari hubungan antara peran PMO dengan keberhasilan pengobatan pasien TB paru, hal ini dikarenakan variable peran PMO dan variable keberhasilan pengobatan masing-masing adalah terdistribusi tidak normal, serta data dari variable skor peran PMO bertipe ordinal dan sumber data masing-masing variable tidak sama. Sumber variable peran PMO diperoleh dari jumlahan skor dari masingmasing skor parameter peran mengawasi, motivasi, mengingatkan, dan penyuluhan. Sumber variable keberhasilan pengobatan diperoleh dari hasil pemeriksaan laboratorium. Rumus untuk memperoleh koefisien korelasi Spearman (R) adalah sebagai berikut :

$$
R=1-\frac{6 \sum b^{2}}{n\left(n^{2}-1\right)}
$$


Tabel 5 Koefisien Korelasi R

\begin{tabular}{cl}
\hline Interval $\mathbf{R}$ & Tingkat hubungan \\
\hline $\mathbf{0} \leq \boldsymbol{R}<\mathbf{0 . 4}$ & Lemah \\
$\mathbf{0 . 4} \leq \boldsymbol{R}<\mathbf{0 . 6}$ & Sedang \\
$\mathbf{0 . 6} \leq \boldsymbol{R} \leq \mathbf{1 . 0 0}$ & Kuat \\
\hline
\end{tabular}

Perhitungan korelasi Spearman Rank pada penelitian ini menggunakan program SPSS, dan hasilnya adalah sebagai berikut :

\section{Correlations}

Tabel 6 Uji Korelasi

\begin{tabular}{|c|c|c|c|c|}
\hline & \multirow{4}{*}{ Y } & \multirow[b]{2}{*}{ Correlation } & Y & \multirow{2}{*}{$\frac{\text { Xtotal }}{.388^{*}}$} \\
\hline \multirow{6}{*}{ Spearman's rho } & & & 1.000 & \\
\hline & & Sig. (2-tailed) & & .013 \\
\hline & & $\mathrm{N}$ & 40 & 40 \\
\hline & \multirow[t]{3}{*}{ Xtotal } & $\begin{array}{l}\text { Correlation } \\
\text { Coefficient }\end{array}$ & $.388^{*}$ & 1.000 \\
\hline & & Sig. (2-tailed) & .013 & . \\
\hline & & $\mathrm{N}$ & 40 & 40 \\
\hline
\end{tabular}

*. Correlation is significant at the 0.05 level (2-tailed).

Dari tabel di atas terlihat bahwa nilai signifikansi $0.013<0.05$, ini berarti hubungan signifikan antara peran PMO dengan keberhasilan pengobatan pasien. Nilai koefisien korelasi $\mathrm{R}$ diperoleh 0.388, maka hubungan antara peran PMO dan keberhasilan pengobatan pasien searah, ini artinya semakin besar peran PMO maka semakin tinggi keberhasilan pengobatan, sebaliknya semakin kecil peran PMO maka semakin rendah keberhasilan pengobatan. Selain itu dari tabel tersebut juga diperoleh bahwa hubungan antara peran PMO dengan keberhasilan pengobatan pasien tergolong lemah karena koefisien korelasi $\mathrm{R}<0.4$.

\section{Kesimpulan}

Hasil uji korelasi Spearman Rank menunjukkan bahwa nilai signifikansi $0.013<0.05$, ini berarti ada hubungan signifikan antara peran PMO dengan keberhasilan pengobatan pasien. Nilai koefisien korelasi $\mathrm{R}$ diperoleh 0.388 , maka hubungan antara peran PMO dan keberhasilan pengobatan pasien searah, ini artinya semakin besar peran PMO maka semakin tinggi keberhasilan pengobatan, sebaliknya semakin kecil peran PMO maka semakin rendah keberhasilan pengobatan. Selain itu nilai $R$ tersebut juga menunjukkan bahwa hubungan antara peran PMO dengan keberhasilan pengobatan pasien tergolong lemah karena koefisien korelasi $\mathrm{R}<0.4$.

\section{Referensi}

[1] WHO. TB Control in the Workplace, Report of an Intercontry Consultan, New Delphi. 2004.

[2] Depkes.RI.2002,http://www.depkes.go.id/index.php?option2 articles\&arcid $=154 \&$ item $=3$

[3] Kemenkes Sumenep. 2016. Profil Kesehatan Dinas Kesehatan Kabupaten Sumenep Tahun 2016. 
[4] Depkes.RI. 2008. Pedoman Penemuan dan Pengobatan Penderita TB Paru. Jakarta. Depkes.

[5] Aditama TY, Subuh M. 2011, Strategi Nasional Pengendalian TB, Kementerian Kesehatan Republik Indonesia Direktorat Jenderal Pengendalian Penyakit Dan Penyehatan Lingkungan

[6] Bachti, 2008. TBC Sembuh Total Dengan Pelayanan DOTS,

[7] Achmadi, U.F. 2005. Manajement Penyakit Berbasis Wilayah, Jakarta : Kompas.

[8] Kementerian Kesehatan RI. (2016). Tentang Pedoman Nasional Pelayanan Kedokteran Tata Laksana Tuberkulosis. Keputusan Menteri Kesehatan RI

[9] Wahyuni dkk. 2016. Hubungan Peran Pengawas Menelan Obat (PMO) terhadap Keberhasilan Pengobatan Tuberkulosis di Puskesmas Kecamatan Johar Baru Jakarta Pusat Tahun 2016. Fakultas Kedokteran Universitas YARSI.

[10] Bumbunan Sitorus, Fatmawati. 2016. Peran Pengawas Menelan Obat (PMO) Terhadap Pengobatan Penderita Tuberkulosa Di Wilayah Kerja Unit Pengobatan Penyakit Paru-Paru (UP4) Pontianak. Fakultas Ilmu Sosial dan Ilmu Politik. Universitas Tanjung Pura Pontianak.Latifatul

[11] Iceu dkk. 2018. Hubungan antara peran pengawas menelan obat (PMO) dengan keberhasilan pengobatan penderita Tuberkulosis Paru Di puskesmas Tarogong Garut. Universitas Padjadjaran Kampus Garut

[12] Saftarina Fitria dkk. 2012. Hubungan Pendidikan dan Pengetahuan Pengawas Minum Obat (PMO) Terhadap Keteraturan Minum Obat Anti Tuberkulosis (OAT) Pada Penderita Tuberkulosis Paru di Kabupaten Tulang Bawang Barat. Fakultas Kedokteran Universitas Lampung

[13] Devi Darliana. 2010. Manajement Pasien Tuberculosis Paru. Fakultas Keilmuan Keperawatan Medikal Bedah Universitas Syiah Kuala.

[14] Puri, A. N., 2010. Hubungan Kinerja Pengawas Minum Obat (PMO) Dengan Kesembuhan Pasien TB Paru Kasus Baru Strategi DOTS. Available from: http:/ / eprints.uns.ac.id/8366/1/132130608201011501.pdf.

[15] Hapsari,R,J.,2010. Hubungan Kinerja Pengawas Minum Obat (PMO) dengan Keteraturan Berobat Pasien TB Paru Strategi DOTS di RSUD dr Moewardi surakarta. Available from: http://core.ac.uk/download/files/478/12349701.pdf

[16] Purwanta, 2005. Ciri-Ciri Pengawas Minum Obat yang Diharapkan Penderita Tuberkulosis Paru di Daerah Urban dan Rural di Yogyakarta. Available from:http://www.jurnal.ugm.ac.id/index.php/jmpk/article/viewFile/2929/264 8 